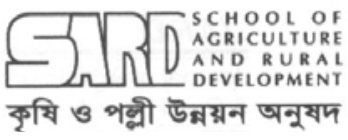

\title{
Indigenous Production Technology of Latkan Practiced in Narsindi District
}

\author{
M.S. ALAM ${ }^{1}$, M. G. MIAH ${ }^{2}$ AND M. K. HASAN ${ }^{3 *}$ \\ ${ }^{1 \&} 2$ Department of Agroforestry and Environment, Bangabandhu Sheikh Mujibur Rahman \\ Agricultural University, Gazipur, Bangladesh \\ ${ }^{3}$ On Farm Research Division, Bangladesh Agricultural Research Institute, Gazipur, Bangladesh
}

A study was carried out at Narsingdi district during July to September, 2003 to investigate the production technologies of Latkan practiced by the farmers. Sixty Latkan growers from six villages under two unions namely, Askitala, Suzathpur and Kamrabo-Betagia of Joynagar union; Gilaber, Sutabandha and Chaitannay of Josohar Bazar were randomly selected for the above purpose. A simple random sampling technique was adopted to collect the necessary information and analyzed by using SPSS 10.0 computer software.

The study revealed that Fifty percent of the farmers were established their Latkan garden within the last 15 years followed by $16-30$ years $(33 \%)$. On an average, the farmers were experienced with Latkan cultivation for 21 years. Land area under Latkan cultivation per farm was on an average of 0.31 hectare and number of trees per farm was 83 . The average number of trees per hectare was 298. Almost cent percent of the farmers (97\%) used saplings as propagating materials and the propagating materials were collected mainly from their own sources $(55 \%)$. No recognized variety was found in the study area. Farmers usually categorized the available cultivars viz. (i) big-size fruit having less sweet and (ii) small-size fruit having sweet to acid in taste. The farmers planted the saplings in the pit and the average pit size was $30 \mathrm{~cm} \times 30 \mathrm{~cm} \times 40 \mathrm{~cm}$. Most of the farmers $(67 \%)$ maintained plant to plant distance for Latkan as 6-7 meters. More than fifty percent of the farmers (57\%) transplanted 2-year old saplings in the main field followed by 3-year old saplings (40\%). About $67 \%$ of the farmers planted sapling in main field during July. About $44 \%$ of farmers had dug soils around the tree once in a year for increasing yield of Latkan. Among them, $33 \%$ of the farmers dug soil around the tree during the month of September-October. Some number of farmers did not apply fertilizers and manures but $42 \%$ of them applied fertilizers and manures during September-October. Many farmers (89\%) pruned their Latkan tree regularly due to its positive effects on flowering of Larkan tree. Among them, $55 \%$ of farmers pruned their Latkan trees once during the month of September-October i.e. after fruit harvesting. Most of the respondent farmers $(83 \%)$ did not apply any irrigation for Latkan cultivation, while, few of the farmers (17\%) applied irrigation twice in a year for Latkan cultivation mostly in March. However, all the respondent farmers opined that if rainfall did not occur timely, inflorescence and young peanut fruits were dropped from the tree because of drought.In most cases (93\%), Latkan trees beard flowers in the month of February-March. In most cases (45\%), farmers identified the ripening symptom of Latkan fruits by light yellow color followed by yellowish-red color (37\%). Fifty percent of the farmers $(50 \%)$ harvested Latkan fruits for the first time after 4 years of transplanting of

\footnotetext{
* Corresponding author: Scientific Officer, OFRD, BARI, Gazipur; Tel. 88-02-9252085; E-mail: kamrulnk@yahoo.com

(C) 2006 School of Agriculture and Rural Development, Bangladesh Open University, All rights reserved.
} 
saplings. About $47 \%$ of the farmers harvested their Latkan fruits in the month of July followed by $33 \%$ in the month of June-July. The storing capacity of the Latkan fruit was very low. Most of the farmers $(65 \%)$ opined that Latkan fruits could be stored for $4-5$ days followed by 2-3 days $(28 \%)$. Anon. (2003) reported most of the farmers responded about the pit size for $30 \mathrm{~cm} \mathrm{X} 30 \mathrm{~cm}$ X40 cm with 4-5 metre spacing and planted in June-July. It also reported that all the farmers did not apply any manures, irrigation and did not practice weeding. Only $15 \%$ of the farmers allowed male tress to grow in their garden with the ratio of male and female plants as $1: 43$. Other farmers $(85 \%)$ did not face any problem due to absence of male tress.

Die back and fruit borer were found as main disease and insect in Latkan trees respectively, but most of the respondent farmers never used any control measure. Majority of the respondents (86 percent) opined that February-March was the flowering time and 47 percent farmers harvested fruits in the month of July. Farmers usually harvested fruits for the first time at about 4 years after planting of saplings. Maximum farmers (83 percent) mentioned that the peak production period was 15-20 years with an average yield of 30-40 Kg/tree, equivalent to 9-12 ton/ha, however, production continued up to 50 years. Sixty-five percent respondent farmers used to sell Latkan fruits in the garden directly and rest of the farmers sold their products either in market or both in market and garden. Most of the respondent farmers (97 percent) planted Latkan as mixed system where Jackfruit and Mango were the dominant tree species.

In the study area, Latkan trees were wild in nature but in recent years, some diseases were reported. Most of the farmers (98\%) opined that Latkan fruits infested by several diseases. About $29 \%$ of the respondents mentioned dieback as major problem followed by of die back plus fruit drop (25\%). Insects those attacked to the Latkan plantations were fruit borer, leaf eating insect, scale insect, ant, etc. But fruit borer was reported as a dangerous insect for Latkan production. About $55 \%$ of the farmers indicated that fruit borers had attacked to the ripened fruit (Table 3 ). They reported that initially borer attacks tender fruits by creating hole and then laid egg in the fruit. When fruits are ripened, larva comes out from the egg and then they eat flesh of the fruits. As a result, fruits are dropped from the tree. On the other hand, only $7 \%$ of the farmers did not observe any insect infestation for Latkan cultivation. To control diseases and insects, few farmers $(11.7 \%)$ used pesticides like Sevin, Dithane M-45 etc.

Latkan trees needed 3-5 years for the first fruit bearing. Initially, the fruit yield was very low, which increased gradually with the increase of age of tree. A 4-year old tree gave only about $4 \mathrm{Kg}$ yield, which was equivalent to 1.1 ton/ha fruit yield. The increment rate of fruit yield from year to year did not follow any trend. However, the increment rate was relatively high at 15 to 20 years tree with an average $30-40 \mathrm{Kg} / \mathrm{tree}$ and in terms of 9-12 t/ha yields. After 20 years, fruit yield increased slowly. Most of the farmers received maximum yield at 25 years of the tree. Then the average yield was found $45 \mathrm{~kg} /$ tree and 13.5 ton/ha with minimum and maximum values of 25 and $125 \mathrm{~kg} / \mathrm{tree}$, respectively. Sometimes, farmers did not get good yield due to excess rainfall and drought during flowering of the tree (Figure 1). There was a positive and strong linear relationship between the age and yield of Latkan, which indicated that the increase of age increased the yield of Latkan. A linear regression of yield of Latkan on the age of Latkan plant was obtained as $\hat{y}=2.1798 x-5.026$ (Fig. 2) The results indicated that the estimated regression could very well be used for predicting yield of Latkan based on the age of plant. That means if we have knowledge of age of the plant, the expected yield from that plant can be estimated. The investigation revealed that almost cent percent of the respondent farmers $(97 \%)$ cultivated Latkan as simultaneous agroforestry system, where Latkan was grown in association with other trees such as Jackfruit (Artocarpus heterophyllus), Mango (Mangifera indica), Litchi (Litchi chinensis), Olive (Olea eropea), Aonla (Phyllanthus officinalis), Jamun (Syzygium cumini), Pummelo (Citrus grandis), Mahagony (Swietonia Macrophylla), Bamboo (Bambosa sp.), etc.

From agronomic and economic point of view, Latkan is a potential crop which has a vast scope to explore. As Bangladesh is situated in the subtropical area, the soil and climatic conditions of Bangladesh are favorable for commercial Latkan production. Although there is no recognized variety of Latkan (Moniruzzaman, 1988) but it has a potential scope for getting high yield of Latkan fruits by improving its yield levels through developing improved varieties and management 
practices. There is a scope to increase yield practicing appropriate agronomic operation like, planting technique, fertilizer management, intercultural operations, agroforestry system, pest management and post harvest technologies.

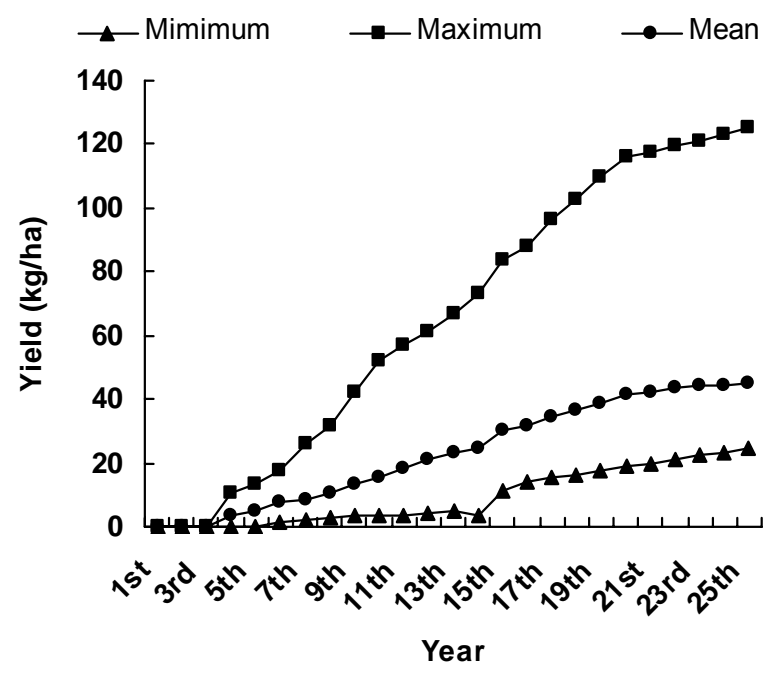

Fig. 1. Yield of Latkan (Kg/tree) at different ages in Narsingdi district

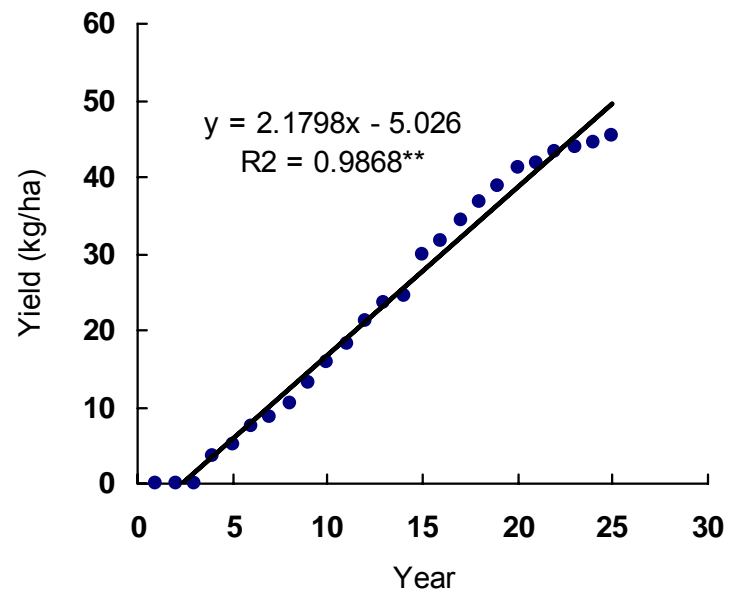

Fig. 2. Relationship between age and yield of Latkan tree

\section{LITERATURE CITED}

Anonymous. 2003. Annual Research Report, 2002-03. On-Farm Research Division, Bangladesh Agricultural Research Institute (BARI), Joydebpur, Gazipur. pp-269 - 275.

Moniruzzaman, F. M. 1988. Bangladesh-a Faler Chash. Bangla Academy, Dhaka. 